\title{
Infinite Revolutions; or, Fred D'Aguiar's Imaginative Response to Western Metaphysical Perceptions of Time
}

\section{Leo Courbot}

\section{CpenEdition}

\section{Journals}

Electronic version

URL: https://journals.openedition.org/ces/824

DOI: $10.4000 /$ ces. 824

ISSN: 2534-6695

\section{Publisher}

SEPC (Société d'études des pays du Commonwealth)

\section{Electronic reference}

Leo Courbot, "Infinite Revolutions; or, Fred D'Aguiar's Imaginative Response to Western Metaphysical Perceptions of Time", Commonwealth Essays and Studies [Online], 42.1 | 2019, Online since 20

December 2019, connection on 23 September 2021. URL: http://journals.openedition.org/ces/824 ; DOI: https://doi.org/10.4000/ces.824

This text was automatically generated on 23 September 2021.

\section{cc) (†)}

Commonwealth Essays and Studies is licensed under a Licence Creative Commons Attribution - Pas d'Utilisation Commerciale - Pas de Modification 4.0 International. 


\section{Infinite Revolutions; or, Fred D'Aguiar's Imaginative Response to Western Metaphysical Perceptions of Time}

\section{Leo Courbot}

In memory of Wilson Harris (1921-2018)

Something happens to time itself. Time switches from a linear narrative to a lyrical sense. Rather than seeing a past that is gone and out of reach, and the fact of a future always presenting itself, there is, instead, a defiance of the linear. The march

forwards may be stalled. The backwards gaze proves not only useful but capable of altering what happened in that past. This idea of time as a continuous present - that is, no past, present, and future continuum, but somehow the past and the future in the present - appeared in Harris's first novel, The Palace of the Peacock (1960), and continued as an imaginative procedure through

twenty-five novels to his latest, The Ghost of Memory (2006). (D'Aguiar 2009b, emphasis added) Wilson Harris' novel The Infinite Rehearsal (1997) foregrounds [the process of revision] as an act of permanent revolution in terms of the writer's evertransforming consciousness. (D'Aguiar 2012, 43, emphasis added). 
1 In his book-length meditative poem Bill of Rights, Anglo-Guyanese and American writer Fred D'Aguiar ${ }^{2}$ has the poetic persona pun on cart and horse, saying that putting "Descartes before the Hobbes / we know and love" would "put an end to verse" (1998, 41). This ironic statement summarizes well D’Aguiar's tendency, like Hobbes $(1909,14)$, and unlike Cartesian metaphysics (Banchetti-Robino 2011, 122), to rationalize the imagination as a reliable form of memory, or gateway to the past, in his works. One of the ways in which D'Aguiar manages to rely on the imagination as a temporal threshold granting access to the past, but also to the future, consists in relying on the late Guyanese writer Wilson Harris' idea of "infinite rehearsal," which has had a significant impact on D'Aguiar's writings. It is indeed no secret that Harris has been a persisting influence on D'Aguiar who, before becoming a successful poet and Harris' friend, intended to write a doctoral dissertation on Harris' works, and then dedicated collections of poems (British Subjects, 35-38; Continental Shelf), a novel (Children of Paradise), and articles - on infinite rehearsal - to Harris ("Prosimetrum" and "Wilson Harris," which are quoted from in the two epigraphs at the beginning of this article).

2 Harris' theory of infinite rehearsal suggests a revisionary take on Nietzsche's concept of perpetual return, insofar as it confirms the cyclical nature of time, but substitutes the recurrence of sameness to the repetition of différance in Derrida's sense of the term, according to which every moment is perceived as a decomposable time differential containing versions of the future and the past. ${ }^{3}$ This view of time notably contradicts the Cartesian dimension of Western metaphysics by making the imagination an integral part of rationality and, in this sense, this article argues, D'Aguiar's recourse to infinite rehearsal translates a revolutionary poetic response to Western-metaphysical perceptions of cyclical time, in addition to infusing his poems with philosophical depth.

In his exploration of Harris' idea, D’Aguiar suggests some of the literary ways in which one may capitalize on the poetic possibilities of infinite rehearsal:

For Harris, each return to a memory, image, or dream yields new insights, and each time the viewer or thinker participates in the recall or act of gazing - from a necessarily partial because particular viewpoint - that person changes a little. [...] The artistic compulsion to look and keep looking at this rich source of selfknowledge creates the sense of a revisionary potential [...]. (2009b)

Rehearsal operates through remembrance and imagination, that is, through representation and/or, possibly, metaphor, which may operate as hypomnesic recurrence, like dreams for instance, since, according to Freud, dreams are the unconscious and metaphorical revisions of past, lived experience $(1985,7)$. In this sense, the literary treatment of infinite rehearsal can rely not simply on tropes of recurrence, but on various revisionary means, and provide different perceptions of the pasts and futures of presence (D'Aguiar 2009b), as can be seen in D'Aguiar's poems “The Trench Revisited" $(1993,35)$ and “Vulture's Theory of Perpetual Return” $(2013,54)$.

Of course, D'Aguiar has relied on infinite rehearsal in many of his works (Courbot 2019, 117-36), but these two short pieces, written twenty years apart, attest to D'Aguiar's continuing interest in Harris' treatment of time, and allow for a direct and concise introduction to its literary implications. Both texts come from cycles of poems. "The Trench Revisited" belongs to the "Frail Deposits" part of British Subjects $(1993,35)$, made up of poems narrating moments D'Aguiar shared with Harris on the occasion of a trip to Guyana (D'Aguiar 2009b). "Vulture's Theory of Perpetual Return" can be found in the "American Vulture" series, from the author's latest collection, The Rose of Toulouse 
(2013, 54). "The Trench Revisited" recounts in verse a life anecdote Harris told to D'Aguiar during their trip to Guyana (D'Aguiar 2009b), and to which the poet reacted by suggesting rehearsals of the story to Harris. "Vulture's Theory of Perpetual Return" corresponds to the description, through a vulture's eyes, of its spiraling flight down to the ground, and relies on many literary techniques which serve to produce meaning through circulation, recurrence, and aerial revolutions.

\section{Trench Trip}

5 The anecdote that provided D'Aguiar with the source material for "The Trench Revisited" consists of a memory that came back to Harris as he and D'Aguiar, in the late 1980s, "walked in a tree-lined street divided by a trench in Georgetown," the Guyanese capital (D'Aguiar 2009b). Harris explained to D'Aguiar that the then dry trench used to be full of water in the 1930s, when he, as a schoolboy, pushed a friend into it, and pretended not to have done a thing as his friend rose back, drenched, from the waters. The friend, as a result, believed he could only blame himself for his ridiculous fall, and decided from then on that he was incorrigibly clumsy. Harris subsequently felt terribly guilty for having caused such an alteration of self-esteem in his friend, and for not having managed to confess that he had actually nudged him into the trench. In that same street in the 1980s, D'Aguiar responded to the story by suggesting that Harris

should push his friend, again, since this time, meaning right then and there, no harm would be done in what was now a dry place. Second, [D'Aguiar] speculated that he, Harris, might look at his friend, falling, back then, from the vantage point of the present, and somehow reach back in time and grab his friend's arm, just in time to save him from getting soaked. And third, should both those methods fail to appeal, or the rescue not work out, somehow Harris could confess to his friend what he had done, again across time, the moment his friend climbed out of the trench. Of course, he might opt simply not to push his friend at all, by suppressing the awful adolescent impulse with the restraint of an adult sensibility, again exercised across time in this shared space. (D'Aguiar 2009b)

Harris "laughed and nodded in recognition" (D'Aguiar 2009b) of D'Aguiar's use of infinite rehearsal, that imaginative technique Harris had been developing from his first novel on, and openly so in The Infinite Rehearsal. Thus, the trench anecdote, during the conversation with Harris, was first rehearsed by Harris as a reminiscence, then represented as a tale to D'Aguiar who, in turn, repeated four varying summaries of that same story which, as a result, was made to recur into différance. A few years later, D'Aguiar revised the anecdote again, along with his moment with Harris, into the sonnet - that is, one of the most "rehearsed" poetic forms of literary history - entitled "The Trench Revisited," which reads as follows:

We're being driven past when you point to Where you'd pushed in a friend long, long ago, Into what was a trench, to test its depth. You say it taught you how a civilisation, Feeling a blow or tug may still not know A hand's involved, so can't feel indebted. I was falling, horizontally, just To keep up and lucky to win your trust. Push him again, he'll fall on land that's dry This time and think nothing of it, and you'll Bank all that knowledge lifted from the sight 
Your friend made clad in mud, convinced totally

That he slipped and your hand on his ribcage

Was your brave, unlucky, one-hand-clap save! $(1993,35)$

In spite of numerous inversions, all of the poem's lines approximate iambic pentameters that "can be read with just sufficient rhythmic heightening to bring out the organization of the meter, but without giving any additional stress to the unstressed syllables functioning as beats" (Attridge 1995, 161) such as "to" and "was." In other words, the iambic pentameter was probably chosen so as to convey the “expressive naturalism” of Harris' and D'Aguiar's conversation (161). Moreover, metrical regularity itself is a pattern of recurrence through which D'Aguiar may make form and sense converge in a poem the theme of which is recurrence: "The Trench Revisited," as its title indicates, is an evident revision - again, an additional recurrence - of a talk he had with Harris. Still in formal terms, the poem's first stanza transcribes the context of that conversation, while the second verse paragraph recounts the first revisionary suggestion D'Aguiar made to Harris. The space between these stanzas could represent the pause in the conversation that was necessary for D'Aguiar to think of how he would respond to Harris' anecdote: the beginning of the reply, "Push him again," is a falling inversion $(/ \mathrm{xx} /)^{4}$ that rhythmically repeats the consequence of Harris' gesture (a fall), culminating with the word "again," the last syllable of which, "gain," falls on the beat, and indicates, again, that repetition may come as a gain: improvement is explicitly described through repetition in the poem's final volta, which, as in an Elizabethan sonnet, has the tables turned by transforming Harris' malevolent "hand" into a benevolent one.

7 But before making his enhancing suggestion, the poetic persona, presumably D'Aguiar here, progressively embodies, in the 1980s, the friend who fell in the trench fifty years before, by depicting himself as "falling, horizontally" in order to keep up with Harris' walking pace, probably slanting his body forward so much that it approximates a horizontal posture that is, in turn, reminiscent of the friend falling flat into the trench. Yet, in spite of the poet's impersonation of the fallen friend, differences abound: while the unlucky man in the trench did not know that a "hand was involved" and that Harris was "indebted" to him (emphasis added), that is, owed him a confession and/or an apology that he did not make, D'Aguiar feels lucky for having gained Harris' trust, expressed through the selection of the poet, who subsequently feels grateful and/or indebted, as the recipient of the confession. ${ }^{5}$ As my italics show, the poet is not the identical double of the fallen friend, but his inverted image, contrasting luck with bad luck, confession with secrecy, and debt with credence.

Furthermore, the scope of the event is distorted by being broadened from the intimacy of the two friends to "a civilisation" which, "Feeling a blow or tug may still not know / A hand's involved, so can't feel indebted" (D'Aguiar 1993, 35). The lines just cited, referring to a late-1980s Georgetown conversation between two writers of Guyanese origins, conjure memories of Forbes Burnham, who was the dictatorial leader of Guyana from 1955 to his death in 1985. For indeed, "a hand [was] involved" in Burnham's rise to power in the Cold War context of the 1950s, although "civilisation" did not know it, since he was backed by the CIA and the British Colonial Office (Naipaul 1982, 34-5) to keep Guyana in the Western block and thwart the communist ambitions of Burnham's former friend and subsequent opponent Cheddhi Jagan. Yet, Burnham did not "feel indebted" to the US or, for that matter, entrenched in the West, since he broke with the USA in 1958, declared Guyana a communist cooperative republic in the years that 
followed, and created bonds with Cuba and the Pan-African movement (37). Thus, in the poem, the very event of the conversation is, along with the tale it contains, driven by the principle of infinite rehearsal, and expands from a private, microcosmic ground to recur to a political and macroscopic past.

The poem is "driven" indeed, as the two writers, in the poem's first line, are "being driven" past the trench. The fact that in the actual story, as told by D'Aguiar in "Prosimetrum," the two authors were walking, might suggest that the stride is rehearsed into a cruise. However, since the poetic persona's self-portrayal is that of a person "falling horizontally" to keep up with Harris' rapid gait, the two characters are actually still walking, and "driven" should then be understood in its metaphorical sense, as a designation of the two authors as "inspired" persons the expression of whose thoughts are guided by outside inspirational forces. The poem's clear reliance on infinite rehearsal shows that Harris' imaginative principle is the "Muse" that dictated D'Aguiar's revisionary poem, along, perhaps, with the more somber, dictatorial figure of Forbes Burnham (Derrida 1991, 19-43). On the other hand, the poem's third line more implicitly conveys a sense of what "drives" Harris: that line specifies that Harris pushed his friend into the trench to "test its depth." Harris' motive is added to the initial story by D'Aguiar so as to function as a reference to Harris' first occupation as a land surveyor of the Guyanese interior, where the puzzling and irregular data he gathered from repeated soundings of rivers and observations of meteorological phenomena occurring in the rainforest led him to devise an imaginative conception of time and space, namely, infinite rehearsal, a principle which, in turn, incited him to write novels translating his vision (D'Aguiar 2009b). Hence, while Harris is driven by nature to the formulation of a theory of infinite rehearsal, D'Aguiar is guided by infinite rehearsal for the formulation of poetry, and such an initial chain of causality, in the poem, is representative of D'Aguiar's connection with Harris, confirmed on the page following “The Trench Revisited" on which D'Aguiar writes that "The flute [he's] trying to blow a tune on / Belongs to [Harris]" (D'Aguiar 1993, 36).

D'Aguiar's poem thus refracts, disjoints the present into recurrent pasts and futures thanks to Harris' theory of infinite rehearsal, to which he feels "indebted" (D'Aguiar 1993, 35). In order to pay back his "debt," D'Aguiar serves Harris' ideas back to him through the suggestion of rehearsing the trench anecdote, by way of which Harris may gain new insight and confess to his friend, subsequently unburdening himself of his sense of guilt, and "bank all [resulting] knowledge" (35), as the poem's final stanza explains. ${ }^{6}$ Another obviously recurrent poem from which readers may "bank" new insights figures in Fred D'Aguiar's latest collection of poems, The Rose of Toulouse.

\section{Vulture Culture}

That poem is, as indicated above, "Vulture's Theory of Perpetual Return," the title and opening lines of which actually function as a poetic definition of Harris' imaginative principle: "I fly up and float on one wingbeat for as long as I can make circles / in the circling winds, I see the same things all the time and all that time / I see those same things differently" (D'Aguiar 2013, 54, emphasis added). The circular movement of the hovering vulture is analogous to that of the "circling winds" of warm air on which its wings rest, doubling up the circular image into a varying recurrence that is also evoked through sound, with the wing/circles pair of words becoming circling/winds, and with the 
alliteration in "fl" that illustrates both the flapping of wings and aerial flotation. As the vulture's flight follows its repetitive, circular trajectory, the bird's recurrent perception of the same elements of landscape, contrarily to what perpetual return suggests, and, perhaps, because of variations in altitude, changes its perception of the scenery. This alteration of vision is visible in the second and third lines of the abovecited tercet, which operate another syntactical mirroring that, again, makes form and sense converge. In addition, these first three lines from D'Aguiar's poem appear to paraphrase Harris's first-person narrator in The Eye of the Scarecrow, when he states that "It was to prove the re-living of all my life again and again as if I were a ghost returning to the same place (which was always different) shoring up different ruins (which were always the same)" $(1965,25)$. According to Hena Maes-Jelinek, these lines define "the substance" of Harris' prose, and are an apt introduction to his principle of infinite rehearsal" (1991, 158-9). In this sense, the vulture's view of perpetual return comprises altering factors, and coheres with a definition of infinite rehearsal as a variant of perpetual return that is inclusive of variation itself: Harris' infinite rehearsal is a "Vulture's Theory of Perpetual Return."

12 The five tercets that follow these opening lines are built on the same type of chiasmatic constructions produced in the poem's first stanza. In them, the vulture describes the recurrent sights offered by its trajectory, and how rehearsed visions impact its thoughts in the process. For instance, in the poem's fourth line, the narrator-bird explains that "The maze in the trees keeps [him] counting the trees in the maze" (D'Aguiar 2013, 54). The syntax may simply sound playful, and the line could come across as tautological. However, the grammatical play through which the same thing is presented twice, yet differently, provides the reader with an enhanced perception of that thing: the interstices of shade between the trees that are offered to the vulture's aerial eye form a maze between the trees that induces the vulture to count the trees constituting such a labyrinth. However, if the trees are "in the maze" as much as they shape it, they may be viewed not only as its walls but as corridors walled with shade. Finally, the "maze in the trees" might designate the same maze being repetitively found in the pattern of every tree's ramifications, that is, a fractal labyrinth of geometrical repetitions that makes any part look like a miniature replica of the whole, infinitely expanding into a dazzling rehearsal that keeps the vulture "counting the trees in the maze," while it can never be sure that it is not seeing the forest for the trees as it hovers down over them.

13 As far as falling is concerned, the downward spiral of stanzas on the page progressively fills with ominous evocations of death, as if the vulture were to crash, and suggests that the bird's trajectory is not only spatial, but also temporal, corresponding to the amount of time the animal has left to live: the death of a vulture in the series' preceding poem corroborates that impression (D'Aguiar 2013, 53). The first description that might come across as dark in "Vulture's Theory of Perpetual Return" appears in the third stanza's final line: "My shadow rides the plains below and thinks it shadow rides the winds" (54). While the vulture's imagining that its "shadow rides the plains" is possible, the reciprocal, mirrored proposition that its shadow "thinks" it imitates the vulture in the sky is presumably impossible: a light source shining on an object casts its shadow, but a shadow cannot be cast on its object to produce light, according to physics. Yet, the imaginative mediation of infinite rehearsal calls those ideas into question, suggesting that rational, physical rules might flow forth from thoughts as solipsistic as those from 
which apparently unreal pictures come. ${ }^{7}$ The spectral image of the thinking shadow may be neither real nor unreal, but could consist in the re-presentation of a becomingspecter of the vulture as it is being silhouetted against the light. In other words, if, in keeping with the theory of infinite rehearsal, the bird's spatial trajectory corresponds to its movement across time, its shadow may adumbrate - "adumbrate" actually meaning, etymologically, "to cast a shadow on" - the coming into existence of a future recurrence of the vulture's flight. In that sense, what the bird is perceiving is the making, syncretized to its past, of its own future, maybe even of its posterity and/or assumed next life cycle, superimposed to its legacies and past lives, if time is indeed cyclical.

It is no wonder, then, to find that from the fourth stanza on, the vulture begins to think of death, for instance, by comparing the loss of a feather to that of a "tooth in a human dead head" (D'Aguiar 2013, 54), an allegorical, skull representation of vanitas ${ }^{8}$ that induces the bird in turn to ponder the fact that, if it was a human being, it would be "destined for a hole in the ground if lucky, / luckier still, to grace a table for vultures" (54): the inversion between vulture and men creates yet another mirror image, and is reminiscent of the death of a vulture under the wheels of a truck driven by a man in the preceding poem in the series (53), suggesting that death too recurs in the poems from "American Vulture." In "Vulture's Theory of Perpetual Return," the vulture also imagines the moment of its death at the hands of an imaginary lamplighter: "The lamplighter who lights all the lamps above / lights the lamps of my eyes and how that lamplighter douses / those cold flames so too my eyes turn dark" (54). The macrocosm of a starry night is reduced to the microcosm of glittering eyes, which then expand again into a starless sky. Such a metaleptic description, by way of which the eye becomes its own planetarium, is a form of bi-directional recurrence that is coherent with the solipsistic impression conveyed by the shadow that "shadow rides the winds," and suggests that when an individual dies, an entire universe disappears with him or her. Yet, the vulture predicts the impact of its death in the following terms: "I belong to no one and no one wants me when I am gone, / to where I do not know, except for the sound just before / silence and the silence just after sound" (54). These last words, forming the poem's closure, complement the experience of a last breath, or sound before the silence of death, with the presentation of posthumous silence as yet another experience, which implies that someone is there to witness that absence of sound. If not the lamplighter or anybody else at the moment of the vulture's death, the poetic voice proleptically, if not prophetically, suggests that it is the bird itself that is to experience an afterlife, or a life in death as it were.

Through that suggestion, the vulture lets readers imagine that its circular and recurrent experience of life has led to the formulation of a "theory of infinite rehearsal" according to which every moment ends only to recur countless times, albeit in different forms that, it is assumed, can be imagined. Such a view of infinite rehearsal as the acquisition of knowledge through a syncretic perception of time can and has been explained thanks to Harris' interest in quantum physics and its "many worlds theory," according to which anything that can happen does actually happen in an infinity of quantum realities (DeLoughrey 2007, 63; Polkinghorne 2002, 52). Yet it appears, in the light of our readings, that Jacques Derrida's notion of différance is another, "original" way in which one may begin to understand infinite rehearsal. ${ }^{9}$ In addition, the correlation of Harris and Derrida, albeit incongruous at first sight, actually points to the like-mindedness of two intellectuals that criticism rarely 
associates, as both Derrida and Harris had been colonial subjects, respectively of France and Britain, who lived in the West, away from their native countries (Algeria and Guyana), for the major part of their lives (respectively from 1962 and 1959 on), and who wrote profusely in forms of prose so complicated and intricate that they still tend to generate heated debates between enthusiastic and skeptical scholars (Courbot 2019, 23 , 132). Derrida's definition of différance, which can help us to understand how Harris' infinite rehearsal differs from Nietzsche's perpetual return, is a case in point:

It is because of différance that the movement of signification is possible only if each so-called "present" element, each element appearing on the scene of presence, is related to something other than itself, thereby keeping within itself the mark of the past element, and already letting itself be vitiated by the mark of its relation to the future element, this trace being related no less to what is called the future than to what is called the past, and constituting what is called the present by means of this very relation to what it is not: what it absolutely is not, not even a past or a future as a modified present. An interval must separate the present from what it is not in order for the present to be itself, but this interval that constitutes it as present must, by the same token, divide the present in and of itself [...]. In constituting itself, in dividing itself dynamically, this interval is what might be called spacing, the becoming-space of time or the becoming-time of space (temporization). And it is this constitution of the present [...] that I propose to call archi-writing, archi-trace, or différance. (Derrida 1982, 13)

Différance, as the condition of signification through difference, the fact that every single sign always-already refers us to the signs it is not in order to become meaningful, implies that a deferral, a time differential, no matter how infinitesimal, is necessary for the sign to make sense. The presence of the sign is hence intrinsically split into its past and its future, and conditions the decomposable nature of origin, or the impossibility of reducing any speakable thing to prime elements. ${ }^{10}$

But if origin is naturally prosthetic, if a word is intrinsically différanciel, then time cannot proceed from a single origin onward into the future in a linear way: if nothing is absolutely original or present, then everything is prosthetic and re-presented, everything is a recurrence from the past and a trace of its future, and time, like tropes, must necessarily circulate. Such a hypothesis on the cyclical progression of time, although not formulated in these terms, is probably what led Nietzsche to devise the notion of perpetual return, most clearly described in Thus Spoke Zarathustra:

All things recur eternal and we ourselves with them, and [...] we have already existed an infinite number of times before and all things with us. [...] [T] here is a great year of becoming, a colossus of a year: this year must, like an hour-glass, turn itself over again and again, so that it may run down and run out anew: so that all these years resemble one another, in the greatest things and in the smallest. (Nietzsche 1969, 236)

That the present always already splits into cyclical recurrence is, again, conceivable. However, one may have reservations as to the necessity for perpetual return to preclude change, by making every cycle the same "in the greatest things and in the smallest," for différance shows that the presence of the present is conditioned by the possibility of its absolute other, by its differing deferral. Repetition entails difference and, hence, the cyclical recurrence of time is not the perpetual return of the same, but the perpetual return of the same as different: recurrence is a variation, a differed and deferred version. In this sense, the cyclical qualities of time could, thus, be more specifically represented as a three-dimensional spiral. 
17 Such a claim to différance as a response to Nietzche's argument is palpable in Harris' idea of "infinite rehearsal" as a variant of perpetual return that is not hermetic to difference, and which exerts a major influence over D'Aguiar's works, as suggested above. Again, what Harris retains from the idea of perpetual return is the potential for events to recur infinitely. However, instants repeat themselves as variants in Harris' conception of infinite rehearsal, and the strict similarity in the revolution of every "great year" is not maintained from Nietzsche. As D'Aguiar explains in this article's first epigraph, in terms reminiscent of Derrida's Shakespearean description of "time out of joints" (see footnote 8), cyclical time turns the present to temporal syncretism, to an infinitely recurring version of presence into différance. Harris further implies that such a reception of time endows the subject with (poetic) agency over it, with the ability to "alter" (Harris 1965, 25; D'Aguiar 2009b) past and future in the present-asrehearsal, by way of which every moment conjures the same future and past specters infinitely, yet with different specificities.

As such, and at the risk of rehearsing our argument in turn, infinite rehearsal, in D'Aguiar's poems, subtly contributes to the satisfaction of his understandable desire, as a creative writer, to subvert the strictures of Cartesian rationality, insofar as Harris' theory of time induces one to rely on the powers of the imagination as a temporal threshold. Through D'Aguiar's imaginative reformulations of infinite rehearsal, Harris' revolutionary mind lives on, like a specter in the spirals of time.

\section{BIBLIOGRAPHY}

ATTRIDGE, Derek. 1995. Poetic Rhythm: An Introduction. Cambridge: Cambridge University Press.

BANCHETtI-ROBinO, Maria Paula. 2011. "Black Orpheus and Aesthetic Historicism: On Vico and

Negritude.” Journal of French and Francophone Philosophy 19, no. 2: 122-35.

BOWERS, Maggie Ann. 2004. Magic(al) Realism: The New Critical Idiom. London: Routledge.

CARPENTIER, Alejo. 1995. “The Baroque and the Marvelous Real.” 1975. In Magical Realism: Theory, History, Community, edited by Lois Parkinson Zamora and Wendy B. Faris, 89-108. Durham: Duke University Press.

COURBOT, Leo. 2019. Fred D'Aguiar and Caribbean Literature: Metaphor, Myth, Memory. Cross/Cultures 208. Leiden: Brill/Rodopi.

D’AGUIAR, Fred. 1993. British Subjects. Newcastle upon Tyne: Bloodaxe Books.

D’AGUIAR, Fred. 1998. Bill of Rights. London: Chatto \& Windus.

D'AGUIAR, Fred. 2003. “Wilson Harris by Fred D’Aguiar.” BOMB Magazine 82 (21 January). https://

bombmagazine.org/articles/wilson-harris/.

D’AGUIAR, Fred. 2009a. Continental Shelf. Manchester: Carcanet. 
D'AGUIAR, Fred. 2009b. "Prosimetrum.” The Caribbean Review of Books (February). http:// caribbeanreviewofbooks.com/crb-archive/19-february-2009/prosimetrum/.

D'AGUIAR, Fred. 2012. “Wilson Harris: The Writer as Surveyor." In Another Life/Une autre vie, edited by Judith Misrahi-Barak and Mélanie Joseph-Vilain, 29-44. Horizons Anglophones, PoCoPages series. Montpellier: Presses Universitaires de la Méditerranée.

D'AGUIAR, Fred. 2013. The Rose of Toulouse. Manchester: Carcanet.

D’AGUIAR, Fred. 2014. Children of Paradise. New York: Harper.

DELOUGHREY, Elizabeth. 2007. "Quantum Landscapes: A Ventriloquism of Spirit." Interventions 9, no. $1: 62-82$.

DERRIDA, Jacques. 1974. “White Mythology: Metaphor in the Text of Philosophy.” New Literary History 6, no. 1: 5-74.

DERRIDA, Jacques. 1982. “Différance." 1972. Margins of Philosophy, 3-27. Translated by Alan Bass. Chicago: Chicago University Press.

DERRIDA, Jacques. 2003. "The Rhetoric of Drugs." High Culture: Reflections on Addiction and Modernity, 19-43. Translated by Michael Israel. Albany: SUNY Press. Originally published as Rhétorique de la drogue. 1990.

FREUD, Sigmund. 1985. Le Rêve et son interprétation. 1899. Paris: Gallimard.

HARRIS, Wilson. 1965. The Eye of the Scarecrow. London: Faber \& Faber.

HARRIS, Wilson. 1987. The Infinite Rehearsal. London: Faber \& Faber.

HOBBES, THOMAS. 1909. “Of

Imagination

Imagination

Imagination." Leviathan. 1651. Oxford: Clarendon Press, 13-18.

MAES-JELINEK, Hena. 1991. “The Wisdom of Uncertainty: 'Re-visionary strategies' in Wilson Harris's The Infinite Rehearsal." In Wilson Harris: The Uncompromising Imagination, edited by Hena MaesJelinek, 157-66. Mundelstrup: Dangaroo Press.

NAIPAUL, Shiva. 1982. Journey to Nowhere: A New World Tragedy. New York: Penguin.

NIETZSCHE, Friedrich. 1969. “The Convalescent.” In Thus Spoke Zarathustra, 236. Translated by R.J. Hollingdale. London: Penguin. Originally published as Also sprach Zarathustra: Ein Buch für Alle und Keinen, 1883-85.

POLKINGHORNE, J.C. 2002. Quantum Theory: A Very Short Introduction. Very short introductions series 69. Oxford: Oxford University Press.

SHAKESPEARE, William. 2008. Hamlet. ca. 1598-1601. Edited by G.R. Hibbard. New York: Oxford.

\section{NOTES}

1. We keep the word in its French spelling, but we do not italicize it, thereby "naturalizing" this supplement to the English language here. 
2. Born in Britain and raised in Guyana, Fred D'Aguiar became an American citizen in 2014 (D'Aguiar 2014, 365).

3. The relevance of these philosophical notions in relation to infinite rehearsal is clarified at the end of this article.

4. I am using the model of single-line scansion presented in Derek Attridge's Poetic Rhythm: An Introduction: stressed syllables are indicated with "/" and unstressed syllables are represented with an "x."

5. "Trust" is foregrounded in "The Trench Revisited," as it forms, with the word "just," the poem's only line-end rime, conveying a sense of D'Aguiar's feeling indebted to Harris for "just" a mere expression of "trust" from a literary forebear he admires. This affection for Harris is corroborated by the poem's final and only internal rime between "brave" and "save," words associated to Harris' rehearsed, corrective gesture, and endowed with meliorative connotations.

6. That Harris may "bank" knowledge from the "bank" of a water trench is reminiscent of Wordsworth's punning on the economy of liquidity in "Tintern Abbey." I discuss the subsequent possibility for a triangulation between Wordsworth, Harris, and D'Aguiar, and for the operation of links between the Orphic tenets of romanticism and magic(al) realism in the fifth chapter of Fred D'Aguiar and Caribbean Literature: Metaphor, Myth, Memory.

7. Such a questioning of reality is, of course, one of the tenets of magic(al) realism which, as a literary genre, questions clear-cut definitions of reality by presenting presumably supernatural events as an integral part of "natural" reality (Bowers 2004, 131).

8. The skull is also one of the key figurations of the baroque movement (see Hamlet), from which Harris borrowed heavily, probably via the Latin American authors writing in Spanish, such as Alejo Carpentier, who made the baroque presentation of landscape into another (creolizing) tenet of magic(al) realism (Carpentier 1995, 89-108). In this light, and as clarified below, it does not seem fortuitous for Derrida to have partly derived différance (which agrees with the implications of infinite rehearsal) from a baroque source as well, that is, Hamlet's description of "time out of joint" (Derrida 1982, 13; Shakespeare 2008, 211-12).

9. Furthermore, as Elizabeth Deloughrey explains, "Plotnitsky reads Werner Heisenberg's 1929 critiques of classical physics (and his concern with the representational efficacy of language) as an important precursor to Derrida" (69). In other words, Derrida's thought, like Harris' idea of infinite rehearsal, among other concepts, would be founded, in part at least, on a seminal text of quantum physics.

10. That is why Derrida favors hauntology over ontology and the metaphoric over the literal - his "favoring" them might also consist in his merely not erasing them, as, according to him, the Western metaphysical tradition does (Derrida 1974, 11).

\section{ABSTRACTS}

This article examines Fred D'Aguiar's poems “The Trench Revisited" and "Vulture's Theory of Perpetual Return" in light of their "revolutionary" reliance on Guyanese novelist Wilson Harris' idea of "infinite rehearsal." Harris' theory of infinite rehearsal suggests a revisionary take on Nietzsche's concept of perpetual return, because it confirms the cyclical nature of time, but substitutes the recurrence of sameness for the repetition of différance (Derrida 1982). ${ }^{1}$ 
INDEX

Keywords: Harris (Wilson), D’Aguiar (Fred), perpetual return, différance, infinite rehearsal

\section{AUTHOR}

\section{LEO COURBOT}

Université de Lille

Leo Courbot is a teaching assistant (PRAG) in English at the University of Lille. He has published articles on cross-cultural theory and Fred D'Aguiar and Wilson Harris' works. His first monograph, Fred D'Aguiar and Caribbean Literature: Metaphor, Myth, Memory, was published by Brill/ Rodopi in March 2019. 